\title{
Methylglyoxal induces glycation and oxidative stress in Saccharomyces cerevisiae
}

\author{
Rashmi S. Tupe ${ }^{1}$ (1) $\cdot$ Anjali Vishwakarma ${ }^{1} \cdot$ Anamika Solaskar $^{1} \cdot$ Anali Prajapati $^{1}$
}

Received: 23 January 2019 / Accepted: 10 July 2019/Published online: 25 July 2019

(C) Università degli studi di Milano 2019

\begin{abstract}
Purpose Hyperglycemia causes abnormal accumulation of methylglyoxal (MGO) and concomitant DNA, protein glycation. These pathophysiological changes further leads to diabetic complications. Yeast Saccharomyces cerevisiae is one of the best model to study MGO-induced glycation modifications. The aim of the present study was to investigate the effect of MGO on protein, DNA glycation, and oxidative stress markers using $S$. cerevisiae as a system.

Methods Saccharomyces cerevisiae cells were incubated with $8 \mathrm{mM}$ of MGO for $4 \mathrm{~h}$ and $24 \mathrm{~h}$. After incubation, protein and DNA samples were isolated from the lysed cells. The samples were analyzed for various glycation (fructosamine, $\beta$-amyloid, free amino group, free thiol group, and hyperchromic shift analysis) and oxidative stress markers (total antioxidant potential, catalase, glutathione, and lipid peroxidation).

Results MGO $(8 \mathrm{mM})$ acted as a potent glycating agent, causing protein and DNA glycation in treated yeast cells. The glycation markers fructosamine and $\beta$-amyloid were significantly elevated when incubated for $4 \mathrm{~h}$ as compared to $24 \mathrm{~h}$. Oxidative stress in the glycated yeast cells alleviated cellular antioxidant capacity and reduced the cell viability.

Conclusion MGO caused significant glycation modifications of proteins and DNA in yeast cells. It also triggered increase in intracellular oxidative stress. MGO-induced protein, DNA glycation, and oxidative stress in $S$. cerevisiae indicate the suitability of the yeast model to study various biochemical pathways involved in diabetic complications and even conformational pathologies.
\end{abstract}

Keywords Saccharomyces cerevisiae $\cdot$ Glycation $\cdot$ Methylglyoxal $\cdot$ DNA $\cdot$ Oxidative stress

\section{Introduction}

Globally, diabetes is becoming an epidemic affecting $\sim 8.2 \%$ adults of the world population (IDF 2015). Diabetes is a metabolic disorder contributing to complications of the heart, blood vessels, eyes, kidney, nerves, and teeth due to increased blood glucose level (Ceriello and Colagiuri 2008). In a hyperglycemic state, the glucose molecules covalently link mainly to long-lived proteins such as collagen, hemoglobin, and DNA resulting in adducts formation through an enzymeindependent process called glycation (Lapolla et al. 2013). Amine-containing molecules like protein, DNA, and lipid

Rashmi S. Tupe

rashmitupe@ gmail.com; rashmi.tupe@ bharatividyapeeth.edu

1 Biochemical Sciences Division, Rajiv Gandhi Institute of IT and Biotechnology, Bharati Vidyapeeth (Deemed to be University), Katraj, Pune 411046, India undergo chemical modification by reaction with reducing sugars resulting in the formation of advanced glycation end products (AGEs) (Hoon et al. 2011). Glycation reaction begins with covalent binding of reducing sugars to proteins and nucleic acids forming unstable Schiff base compounds, which convert to a more stable Amadori product-fructosamine. Fructosamine undergoes complex series of reactions to become irreversibly cross-linked, heterogeneous derivativesAGEs (Vlassara and Uribarri 2014). Persistent hyperglycemia leads to an increased formation of endogenous metabolites such as methylglyoxal (MGO), glyoxal, and 3-deoxyglucose. All these derived moieties act as precursors for AGE formation (Miranda et al. 2016) with MGO as the most significant and highly reactive glycating agent. MGO is continuously produced by irreversible $\beta$-elimination of the phosphate group from dihydroxyacetone phosphate and D-glyceraldehydes-3phosphate (Baig et al. 2017).

MGO exerts profound effects on structure, function, and stability of protein and DNA molecules. Tertiary protein 
structure is disrupted due to protein aggregation ( $\beta$-amyloid) and modified lysine and arginine residues of protein (Botstein and Fink 2011). Similarly, DNA structure is also affected by its unwinding and fragmentation. Additionally, oxidative stress increases with glycation modifications due to more carbonyl species generations and reduction in cellular antioxidant capacity. Saccharomyces cerevisiae is a perfect model organism to study disease biology due to its rapid rate of multiplication, similarities in biological, cellular organization, and presence of $20 \%$ counterpart of the human disease genes (Gomes et al. 2006). However, it is seldom used as model to study cellular glycation, hyperglycemia, and associated oxidative stress. Overall glycation reaction has been reported to activate a cascade of downstream apoptotic pathway in $S$. cerevisiae causing decreased cell viability (Gomes et al. 2008a, b).

In present study, S. cerevisiae was used as a model organism to study the effects of MGO on protein and DNA glycation modifications. The glycation markers (fructosamine, $\beta$ amyloid, free amino group, free thiol group, and hyperchromic shift analysis) were determined from protein and DNA samples. Furthermore, the action of MGO glycation on cellular oxidative stress was analyzed by estimating cellular antioxidants (total antioxidant activity, catalase activity, reduced glutathione (GSH), and lipid peroxidation content).

\section{Materials and methods}

\section{Yeast strain and culture condition}

Saccharomyces cerevisiae strain BY4741 was procured from the National Collection of Industrial Microorganisms (NCIM), Pune, India. It was maintained on YPD ( $0.5 \%$ yeast extract, $1 \%$ peptone, and $2 \% \mathrm{D}$-glucose) agar slants $(2 \%$ agar). For use in experiments, the cells were inoculated in YPD broth and incubated in an orbital shaker $\left(37^{\circ} \mathrm{C}\right.$, $150 \mathrm{rpm})$ for $24 \mathrm{~h}$.

\section{Determination of $\mathrm{EC}_{50}$ value of $\mathrm{MGO}$}

The MGO concentration having a half maximal response on yeast cells was determined from a range of concentrations varying from 0 to $50 \mathrm{mM}$. Cell viability assay was performed by incubating the cells $\left(5 \times 10^{8} \mathrm{cfu} / \mathrm{ml}\right)$ with MGO in YPD media. The viability of cells was checked at different time intervals $(0,3,5,24$, and $48 \mathrm{~h})$. The half maximal effective concentration $\left(\mathrm{EC}_{50}\right)$ value is calculated from the graph where $50 \%$ viability was observed (Ispolnov et al. 2008). The results were further confirmed by spot assay. For the 10-fold serial dilution spot assay, viability of yeast cells was checked at different time intervals $(0,3,24$, and $48 \mathrm{~h})$ by inoculating serially diluted yeast culture as a spot on YPD agar plate (Hoon et al. 2011).

\section{Glycation of yeast cells}

Cells were harvested at the exponential phase and two sets of cell suspensions $\left(5 \times 10^{8} \mathrm{cfu} / \mathrm{ml}\right)$ with $8 \mathrm{mM}$ MGO (prepared in phosphate buffered saline) in YPD media were incubated at $37{ }^{\circ} \mathrm{C}$ for $4 \mathrm{~h}$ and $24 \mathrm{~h}$, respectively. Untreated control (cells without MGO) and standard glycation inhibitor aminoguanidine (AG) control (cells $+\mathrm{MGO}+\mathrm{AG}$ ) were maintained simultaneously. After incubation, the samples were centrifuged at $10,000 \mathrm{rpm}$ for $10 \mathrm{~min}$ and the cell pellets were resuspended in $4 \mathrm{ml}$ of $0.85 \% \mathrm{NaCl}$ (Maeta et al. 2005). The experiment was performed in triplicates under aseptic conditions.

\section{Preparation of cell lysate}

The cell lysate was prepared by adding $1.5 \mathrm{ml}$ cell lysis buffer (0.1 mM EDTA, 2 mM DTT, 1 mM PMSF, and 0.5 M potassium phosphate buffer) to the cell pellet, followed by $30 \mathrm{~min}$ sonication at $20 \mathrm{kHz}$. Cell debris was removed by centrifugation at 10,000 rpm for $30 \mathrm{~min}$. The supernatant obtained was used for analysis of glycation and antioxidant markers. Protein concentration of the cell lysate was estimated by Lowry's method and expressed as milligram protein per milliliter sample (Stathopulos et al. 2004).

\section{Isolation of DNA samples}

For DNA isolation, the cell pellet was mixed with $2 \mathrm{ml}$ DNA lysis buffer (2-phenol/chloroform/isoamyl alcohol solution in the ratio 25:24:1) and sonicated for $20 \mathrm{~min}$ at $20 \mathrm{kHz}$. The mixture was centrifuged at $5000 \mathrm{rpm}$ for $10 \mathrm{~min}$. The supernatant was mixed with $600 \mu \mathrm{l}$ of $95 \%$ alcohol and kept at $20{ }^{\circ} \mathrm{C}$ for $30 \mathrm{~min}$. It was then centrifuged at $2000 \mathrm{rpm}$ for $15 \mathrm{~min}$, air-dried for $30 \mathrm{~min}$. The final sample obtained was resuspended in sterile distilled water (Tan and Yiap 2009) and used for further analysis.

\section{Evaluation of glycation markers}

\section{Fructosamine estimation}

Fructosamine levels were measured spectrophotometrically using nitroblue tetrazolium (NBT) reduction assay (Ayyappan et al. 2015). Briefly, $40 \mu$ l of protein/DNA sample was added to $0.8 \mathrm{ml}$ of NBT $(0.7 \mathrm{mM}$ in $1 \mathrm{M}$ sodium carbonate buffer; $\mathrm{pH} 10.35$ ) and incubated for $30 \mathrm{~min}$ at $37{ }^{\circ} \mathrm{C}$. Fructosamine level was estimated by measuring absorbance at $540 \mathrm{~nm}$ (UV-10 spectrophotometer, Thermo Fisher Scientific, USA). Results were expressed as nanomole fructosamine per milligram protein. 


\section{$\beta$-Amyloid estimation}

Amyloid formation in glycated yeast protein and DNA samples was estimated by amyloid specific Congo red dye (Miroliaei et al. 2017). Briefly, $100 \mu l$ glycated sample was added to $400 \mu \mathrm{l}$ phosphate buffer $(\mathrm{pH}$ 7.2) and then mixed with $100 \mu \mathrm{l}$ of Congo red solution. Congo red $(100 \mathrm{mM})$ was prepared in PBS (pH 7.4) containing ethanol $(10 \% v / v)$. The reaction mixture was incubated in dark for $20 \mathrm{~min}$. After incubation, the absorbance was measured at $530 \mathrm{~nm}$. Results were expressed as nanomole $\beta$-amyloid per milligram protein.

\section{Estimation of protein carbonyl group}

Protein carbonyl group was estimated by the method of Uchida et al. (1998). Glycated protein sample $(0.5 \mathrm{ml})$ was mixed with $0.5 \mathrm{ml}$ of $20 \% \mathrm{TCA}$ and $0.5 \mathrm{ml}$ of 2,4dinitrophenylhydrazine $(0.01 \mathrm{M}$ in $2.5 \mathrm{M} \mathrm{HCl})$. The mixture was incubated at room temperature for $60 \mathrm{~min}$. After incubation, the mixture was centrifuged at $7000 \mathrm{rpm}$ for $5 \mathrm{~min}$. The pellet obtained was washed with $0.5 \mathrm{ml}$ of 1:1 ethanol and ethyl acetate, dissolved in $1 \mathrm{ml}$ of $6 \mathrm{M}$ urea, and centrifuged at $7000 \mathrm{rpm}$ for $10 \mathrm{~min}$. Absorbance of the supernatant was measured at $365 \mathrm{~nm}$ and $280 \mathrm{~nm}$. The concentration of protein carbonyl group was calculated by using a molar extinction coefficient $\varepsilon_{365 \mathrm{~nm}}=21 / \mathrm{mM} / \mathrm{cm}$. The results were expressed as nanomole carbonyl per milligram protein.

\section{Estimation of free amino group}

Free amino group was estimated by the method of Acimovic et al. (2011). Glycated protein sample $(100 \mu \mathrm{l})$ was incubated with $100 \mu$ lof potassium phosphate buffer (pH 7.2) and $40 \mu \mathrm{l}$ of $0.1 \mathrm{M}$ p-benzoquinone in DMSO. Volume was made up to $1500 \mu \mathrm{l}$ with distilled water and absorbance was measured at $480 \mathrm{~nm}$. The results were expressed as nanomole per milligram protein.

\section{Estimation of free thiol (-SH) group}

For free thiol group estimation, reaction was started by adding $0.25 \mathrm{ml}$ of glycated protein to $0.75 \mathrm{ml}$ of $0.5 \mathrm{mM}$ Ellman's reagent (DTNB) prepared in $1 \times$ phosphate-buffered saline ( $\mathrm{pH}$ 7.2). The reaction mixture was kept at room temperature for $15 \mathrm{~min}$ and the absorbance was measured at $412 \mathrm{~nm}$. The concentration of the thiol group was calculated by using the molar extinction coefficient $(13.6 / \mathrm{mM} / \mathrm{cm})$ and results were expressed in nanomole free thiol per milligram protein (Winther and Thorpe 2014).
UV-visible spectroscopic analysis of DNA

The absorption spectra of untreated and modified DNA $(100 \mu \mathrm{g} / \mathrm{ml})$ was recorded at the wavelength range 200 $400 \mathrm{~nm}$ on UV-visible spectrophotometer (Baraka-Vidot et al. 2014).

\section{DNA thermal melting temperature}

Melting temperature of glycated DNA was estimated by percent denaturation. DNA sample $(100 \mu \mathrm{g})$ was dissolved in $1 \mathrm{ml}$ melting buffer $\left(0.05 \mathrm{mM}\right.$ EDTA, $1 \mathrm{mM} \mathrm{Na}_{2} \mathrm{CO}_{3}$, and $1 \mathrm{mM} \mathrm{NaCl}$ in distilled water) and incubated in water bath at $30-90{ }^{\circ} \mathrm{C}$ with increase in temperature at a rate of $5{ }^{\circ} \mathrm{C} / \mathrm{min}$. Melting temperature was estimated by measuring absorbance at $260 \mathrm{~nm}$ (Wani et al. 2012).

\section{Evaluation of cellular antioxidant potential}

\section{Measurement of total antioxidant capacity}

Total antioxidant capacity was estimated by ferric reducing antioxidant power assay (FRAP) (Benzie and Strain 1996). For this assay, $100 \mu \mathrm{l}$ of the cell lysate was mixed with $3.6 \mathrm{ml}$ of FRAP reagent (acetate buffer $\mathrm{pH} 3.6 / \mathrm{FeCl}_{3} \cdot \mathrm{H}_{2} \mathrm{O}$ / tripyridine triazide, 10:1:1) and $0.4 \mathrm{ml}$ distilled water. The absorbance was measured at $593 \mathrm{~nm}$ at $0 \mathrm{~min}$ and after $4 \mathrm{~min}$. Ascorbic acid standard $(0.1-1.5 \mathrm{mM})$ was processed similarly. The results were expressed as micromole of reduced ferrous as total antioxidant capacity.

\section{Estimation of GSH}

GSH content of the samples was assayed by the method of Ellman (1959). Briefly, $250 \mu$ l of glycated protein sample was added to $400 \mu \mathrm{l}$ of precipitating buffer (5\% trichloroacetic acid in $1 \mathrm{mM}$ EDTA buffer). The protein precipitate was separated by centrifugation at $3000 \mathrm{rpm}$ for $10 \mathrm{~min}$. Supernatant $(80 \mu \mathrm{l})$ was mixed with $2000 \mu \mathrm{l}$ of phosphate buffer $(0.1 \mathrm{M}$; $\mathrm{pH} 8.0)$ and $80 \mu \mathrm{l}$ of $0.01 \%$ DTNB (5,5'-dithiobis-(2nitrobenzoic acid)). Absorbance of the yellow color complex was measured at $412 \mathrm{~nm}$ within 10 min against protein blank. GSH concentration was calculated by using the molar extinction coefficient $13600 \mathrm{l} / \mathrm{M} / \mathrm{cm}$. Results were expressed as nanomole of GSH per milligram protein.

\section{Estimation of catalase activity}

Catalase activity of the samples was estimated by the modified method of Aebi (1984). Glycated yeast protein $(50 \mu \mathrm{l})$ was mixed with $284 \mu \mathrm{l}$ of potassium phosphate buffer $(1 \mathrm{M}$; $\mathrm{pH}$ 7.0) and reaction was initiated by addition of $160 \mu \mathrm{l}$ of 
$30 \mathrm{mM} \mathrm{H}_{2} \mathrm{O}_{2}$. Absorbance was measured at $0 \mathrm{~min}$ and $1 \mathrm{~min}$. Results were expressed as nanomole per milligram protein.

\section{Analysis of lipid peroxidation}

Lipid peroxidation in treated yeast samples was analyzed by measuring malondialdehyde (MDA) using the method of Placer et al. (1966). For this, $0.4 \mathrm{ml}$ of protein sample was mixed with $0.8 \mathrm{ml}$ of TCA (3\%) followed by centrifugation at $3000 \mathrm{rpm}$ for $15 \mathrm{~min}$. Supernatant $(0.8 \mathrm{ml})$ was mixed with $1.2 \mathrm{ml}$ of thiobarbituric acid $(0.67 \%$ in $0.25 \mathrm{mM} \mathrm{HCl})$. The mixture was incubated in water bath for $30 \mathrm{~min}$ at $100^{\circ} \mathrm{C}$. The absorbance was measured at $532 \mathrm{~nm}$. Concentration of MDA was calculated using the molar extinction coefficient $15300 \mathrm{l} /$ $\mathrm{M} / \mathrm{cm}$. Results were expressed as nanomole of MDA per milligram protein.

\section{Statistical analysis}

Statistical analysis was carried out by using MS Office Excel and GraphPad Prism software. Data were expressed as the mean \pm standard deviation. Results were subjected to oneway analysis of variance (ANOVA) followed by multiple comparison tests by computing critical difference (C. D.). The levels of significance were denoted as $* p<0.05$, $* * p<0.01$, and $* * * p<0.001$ in comparison with positive control.

\section{Results}

\section{Determination of $\mathrm{EC}_{50}$ of $\mathrm{MGO}$ concentration}

$\mathrm{EC}_{50}$ of MGO for $S$. cerevisiae was $8 \mathrm{mM}$ (Fig. 1a). Spot assay was performed to confirm the toxicity of $8 \mathrm{mM}$ MGO (Fig. 1b). It was observed that the viability of the cells decreased significantly in MGO-treated cells as compared to the cells treated with AG. Further, the cell viability was reduced significantly in $48 \mathrm{~h}$ incubation as compared to $3 \mathrm{~h}, 5 \mathrm{~h}$, and $24 \mathrm{~h}$, indicating time-dependent toxicity of MGO to the yeast.

\section{Effect of MGO on different glycation markers of yeast cellular proteins at 4 and $24 \mathrm{~h}$}

The presence of MGO in the treatment media caused remarkable increase in all glycation markers in yeast cells, whereas addition of AG exerted its inhibitory effect on MGO glycation. Fructosamine content was found to be significantly high $(p<0.001)$ in the glycated cells as compared to untreated and inhibitory control. Fructosamine content was 0.8 -fold higher in $4 \mathrm{~h}$ glycated sample than $24 \mathrm{~h}$ (Fig. 2a). The amyloid structure was significantly elevated in glycated cells incubated for $4 \mathrm{~h}$ and $24 \mathrm{~h}$ as compared to untreated and inhibitory control (Fig. 2b). $\beta$-Amyloid formation was 1 -fold higher in $4 \mathrm{~h}$ glycated cells than $24 \mathrm{~h}$ treatment. Oxidation of protein showed an increase in carbonyl level in the glycated sample as compared to untreated and inhibitory control with 1-fold increase in carbonyl group in $24 \mathrm{~h}$ glycated cells as compared to $4 \mathrm{~h}$ treatment (Fig. 2c). Figure 2d, e depicts 1-fold decrease in free amino and the thiol group in glycated yeast proteins in $4 \mathrm{~h}$ glycated sample as compared to $24 \mathrm{~h}$ treatment $(p<0.001)$.

\section{Effect of MGO on different glycation markers of yeast DNA}

The DNA samples isolated from MGO-treated samples showed relative increase in fructosamine levels as compared to untreated samples. The presence of $A G$ in the treatment media resulted in inhibitory action on glycation as evident from reduction of fructosamine level ( $p<0.01$; Fig. 3a). Similarly, as shown in Fig. 3b, MGO treatment induced DNA amyloid formation $(p<0.001)$ as compared to untreated and inhibitory control.

Increased hyperchromicity at $260 \mathrm{~nm}$ was observed in glycated DNA as compared to untreated and inhibitory control (Fig. 3c). The peak at $330 \mathrm{~nm}$ indicates the hyperchromic shift in DNA due to glycation. Melting temperature of untreated and modified DNA was analyzed in temperature range of 30 $95^{\circ} \mathrm{C}$. Melting temperatures of untreated and inhibitory control were found to be $83{ }^{\circ} \mathrm{C}$ and $81{ }^{\circ} \mathrm{C}$, respectively, whereas for glycated DNA, it was $78^{\circ} \mathrm{C}$ (Fig. 3d).

\section{Effect of MGO on oxidative stress markers of yeast cellular protein for 4 and $24 \mathrm{~h}$}

As seen in Fig. 4a, the oxidative stress in MGO-treated yeast cells was found to be increased with reduction in antioxidant capacity as compared to the untreated and inhibitory control. There was no significant difference in antioxidant capacity between 4 and $24 \mathrm{~h}$ treatment, but it was evident from Fig. $4 \mathrm{~b}$, c that free radical scavenger GSH and catalase content were decreased $(p<0.01)$ in the glycated cells as compared to untreated and inhibitory control. The lipid peroxidation was significantly elevated $(p<0.001)$ in glycated yeast cells as compared to untreated and AG-treated inhibitory control (Fig. 4d). However, for $4 \mathrm{~h}$ and $24 \mathrm{~h}$ treatment, the rate of peroxidation did not change significantly with time.

\section{Discussion}

Saccharomyces cerevisiae BY4741 was used as a model organism in our glycation studies due to its rapid rate of multiplication and similarities with various biochemical, metabolic pathways of human cells (Hartwell 2002). Yeast has been used 
Fig. 1 Estimation of MGO concentration to study glycationinduced modification in yeast. a The half maximal effective concentration $\left(\mathrm{EC}_{50}\right)$ of MGO corresponding to $50 \%$ cell viability. $\mathbf{b}$ Spot assay of treated yeast cells (a)

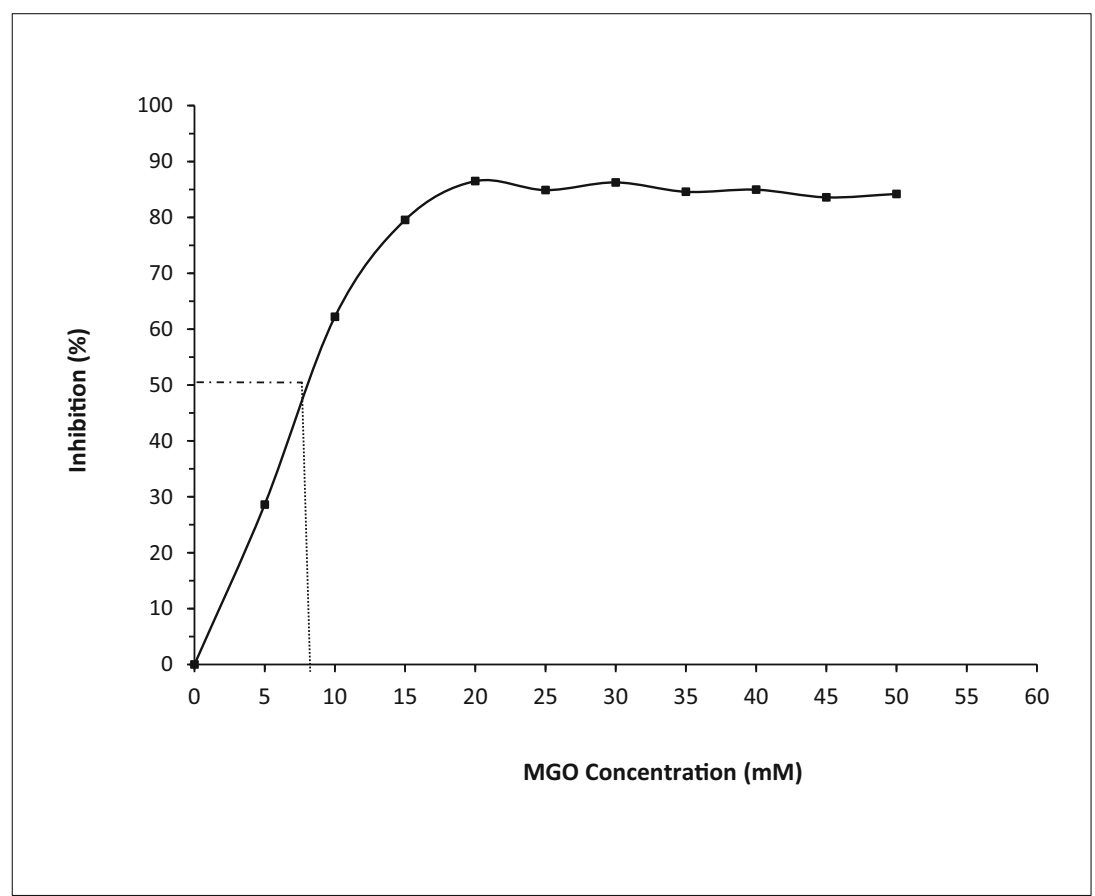

(b)

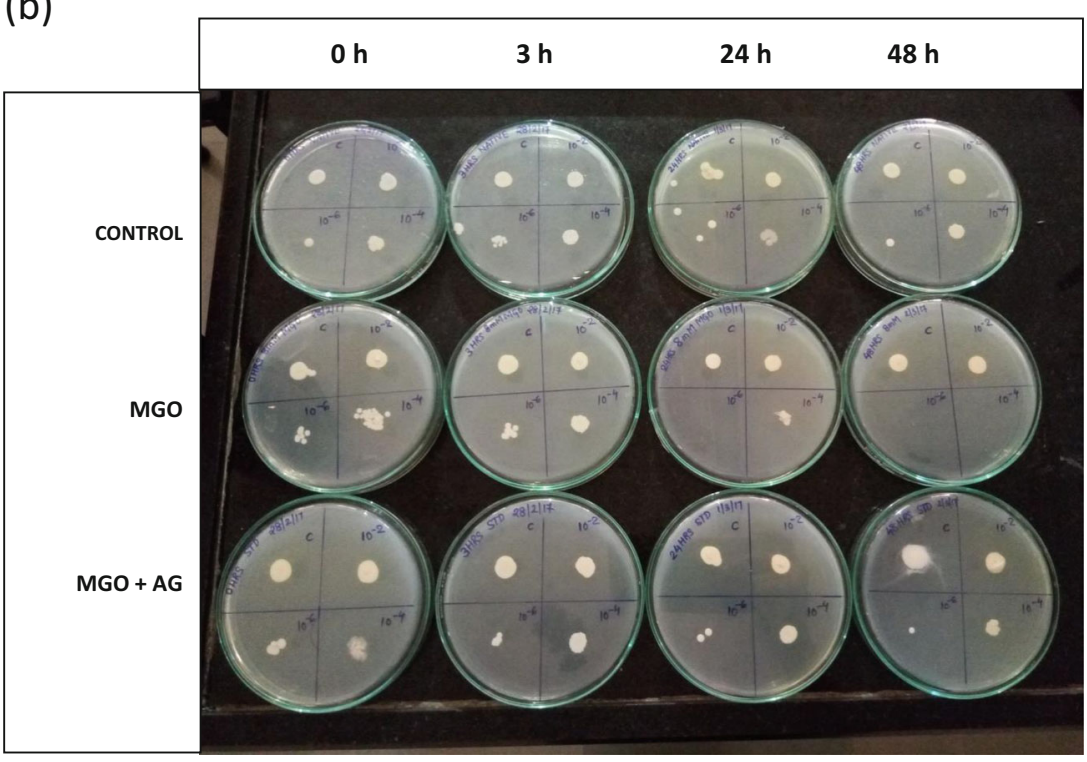

extensively to study disorders related to protein dysfunction (Mohammadi et al. 2015), antiglycation defenses (Ponces Freire et al. 2003), glycolytic effect, and glucose-related metabolic disorders (Petranovic et al. 2010). Further glycation effects have been studied in various cells such as platelets (Soaita et al. 2017) and proteins - albumin (Raghav et al. 2017). Additionally, MGO showed profound effects on cell viability and oxidative stress indicating its implication on the pathophysiology and complications of obesity and diabetes (Matafome et al. 2013). However, there are no comprehensive findings for yeast cells with respect to MGO-induced glycation changes of protein and DNA samples. Therefore, the present work was aimed to specifically study the effect of MGO on structural, glycation markers of yeast with focus on the protein and DNA modifications (Fig. 5).

Membrane receptors serve as a place for the ligand binding during signal transduction induction. The yeast cell senses glucose through the cell surface glucose receptors Rgt2 and Snf3, which generate the signal for induction of genes involved in glucose uptake and metabolism (Roy and Kim 2014). Intracellular glucose undergoes glycolysis and MGO is generated as a byproduct (Aguilera and Prieto 2004). In contrast to 
(a)

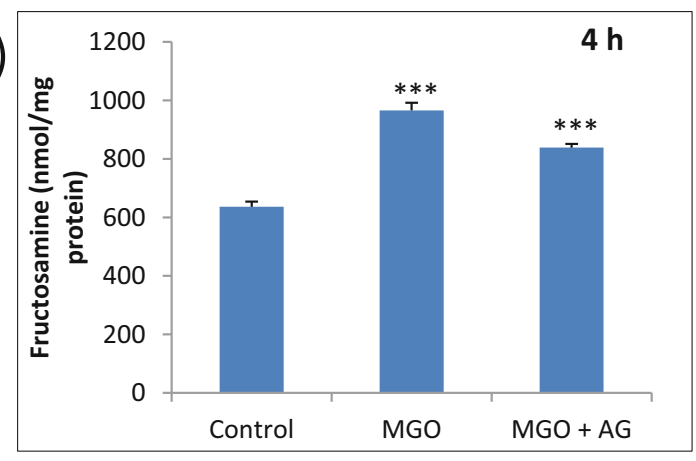

(b)

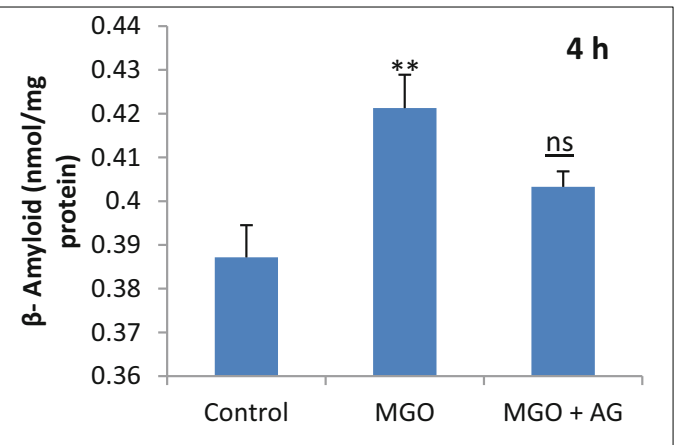

(c)

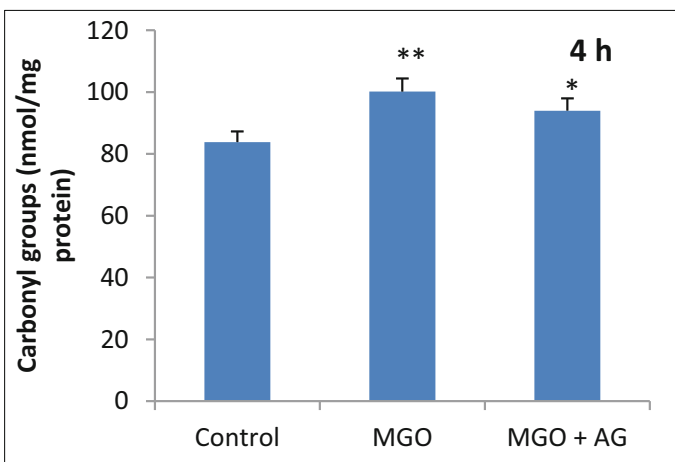

(d)

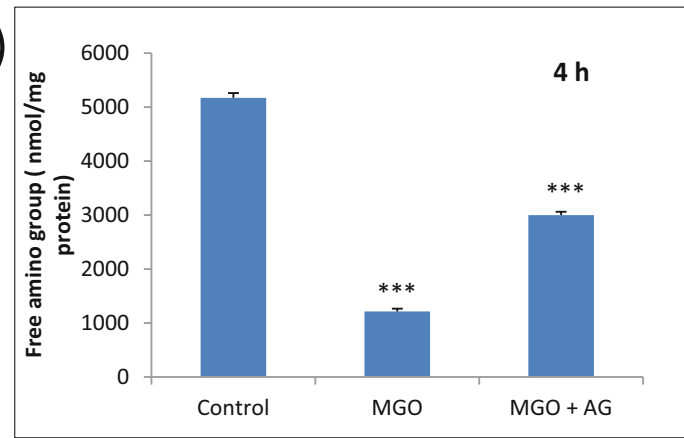

(e)

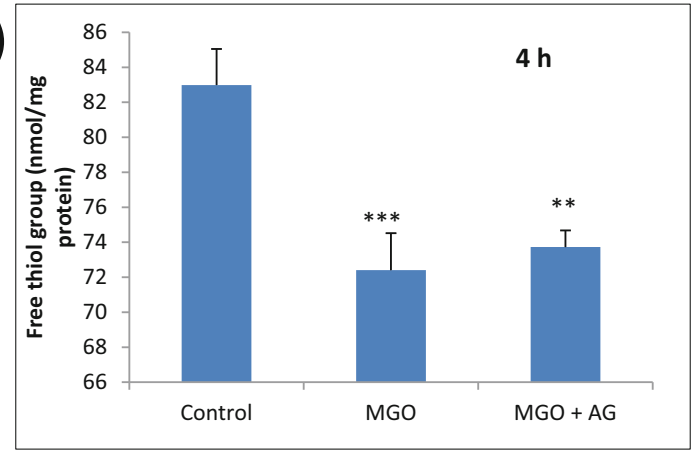

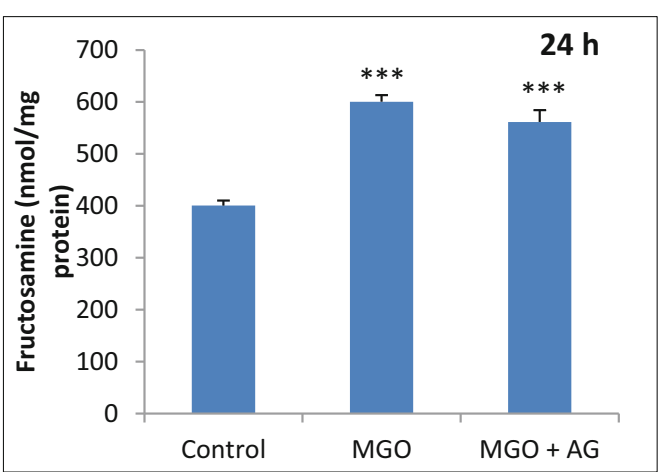
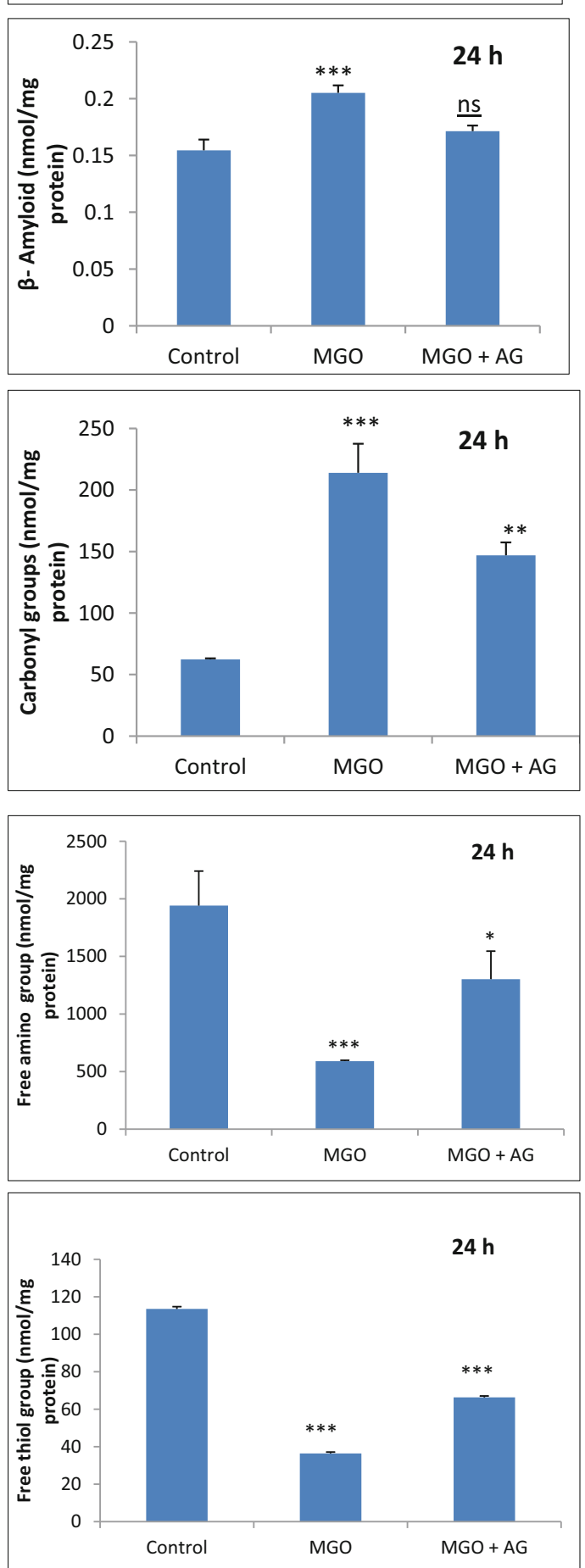
Fig. 2 Effect of MGO on different glycation markers of yeast cellular protein at $4 \mathrm{~h}$ and $24 \mathrm{~h}$. a Fructosamine, b $\beta$-amyloid, c carbonyl groups, d free amino groups, and e free thiol groups. Results are expressed as mean $\pm \mathrm{SD}, n=3$. The significance of the result is determined by comparing the untreated control and inhibitory control with $\mathrm{MGO}$ treated yeast cells using one-way ANOVA and represented as $* p<0.05$, $* * p<0.01, * * * p<0.001$

human cells having receptor for AGEs (Inoue et al. 1998), yeast cell surface internalizes MGO by endocytosis through AGEspecific receptor causing a deleterious effect on yeast cell. A higher concentration of MGO (intracellular and extracellular) induces a couple of signaling molecules escalating ROS production and thereby increasing oxidation reaction in the cell. Additionally, recent reports indicated that MGO inhibits the growth of glucose fermenting yeast cells by inducing endocytosis and degradation of the glucose sensors (Roy et al. 2016).

As glycation is a time-dependent process, in the present study glycation of the cells was carried out for different time intervals $(0,3,5,24$, and $48 \mathrm{~h})$. Two time intervals $4 \mathrm{~h}$ and $24 \mathrm{~h}$ were considered for glycation studies from spot assay. It was observed from spot assay that below $3 \mathrm{~h}$, viability of cell did not change and above $24 \mathrm{~h}$, all cells were dead. At 4 and $24 \mathrm{~h}$, MGO showed significant glycation effect on protein and DNA, which was evident from levels of the number of glycation markers as compared to untreated and inhibitory control. MGO glycation of proteins, DNA, and oxidative (a)

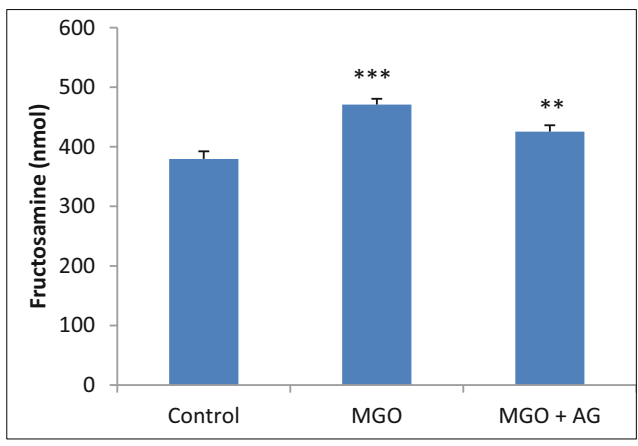

(c)

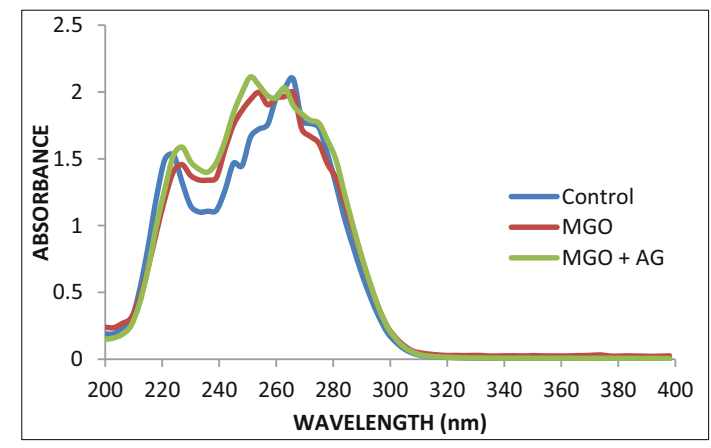

Fig. 3 Effect of MGO on different glycation markers of yeast DNA. a Fructosamine and $\mathbf{b} \beta$-amyloid. Results are expressed as mean $\pm \mathrm{SD}, n=$ 3. The significance of the result is determined by comparing the untreated control and inhibitory control with MGO-treated yeast cells using oneway ANOVA and represented as $* p<0.05, * * p<0.01$, *** $p<0.001$. c Hyperchromicity shift analysis-normalized absorption spectra of stress was moderate in the presence of AG. AG is known to readily react with $\alpha, \beta$-dicarbonyl compounds and prevent AGE formation by not allowing reducing sugar to get attached to protein residues (Thornalley 2003).

Fructosamine is an early glycation marker found in the cells under high glucose level (Horvat and Jakas 2004) and considered as an early Amadori product formed through a highly stable irreversible and non-enzymatic reaction (Ansari et al. 2011). This may be the reason for the higher levels of fructosamine in $4 \mathrm{~h}$ glycated samples as compared to $24 \mathrm{~h}$ treated yeast cells. Additionally, MGO binds to free amino groups of proteins and results in the formation of crosslinked aggregates termed as $\beta$-amyloid ( $\mathrm{Li}$ et al. 2012). $\beta$ Amyloid formation does not allow tertiary protein folding and aggregated unfolded protein structure causes cell death by generating reactive oxygen species (Dalle-Donne et al. 2003; Klunk et al. 1999). Congo red specifically binds to the cleft between amyloid structures, therefore, used to detect amyloidosis. With an increase in time span after treatment with MGO, yeast cells showed an increase in the level of reactive oxygen species, indicating higher oxidative stress. Carbonyl derivatives are formed as a result of protein oxidation (Birben et al. 2012); its level was found to be increased in $24 \mathrm{~h}$ of the glycated sample as compared to $4 \mathrm{~h}$. The free amino group was considerably lower in $4 \mathrm{~h}$ glycated cells as compared to $24 \mathrm{~h}$. This could be possibly because of MGO readily getting

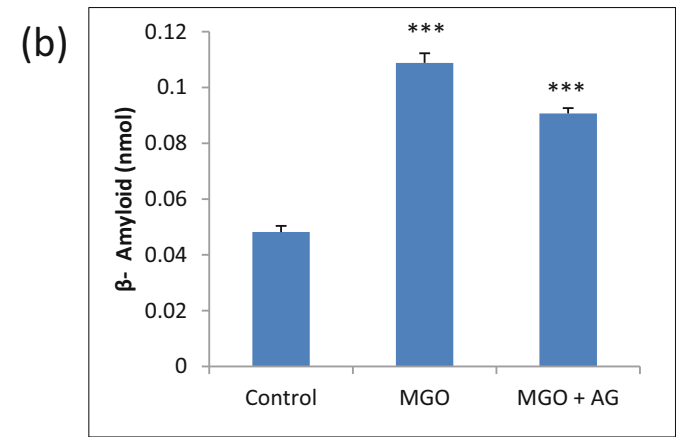

(d)

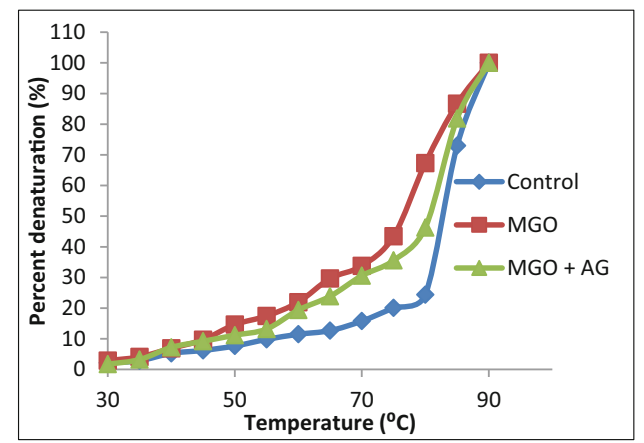

untreated DNA (blue color), DNA + MGO (red color), $\mathrm{MGO}+\mathrm{AG}$ (green color). Result is expressed as hyperchromic shift at $260 \mathrm{~nm}$ by comparing untreated control and inhibitory control with MGO-treated yeast cells. $\mathbf{d}$ Thermal melting temperature - $\%$ denaturation of untreated DNA (blue color), DNA + MGO (red color), and MGO + AG (green color) 

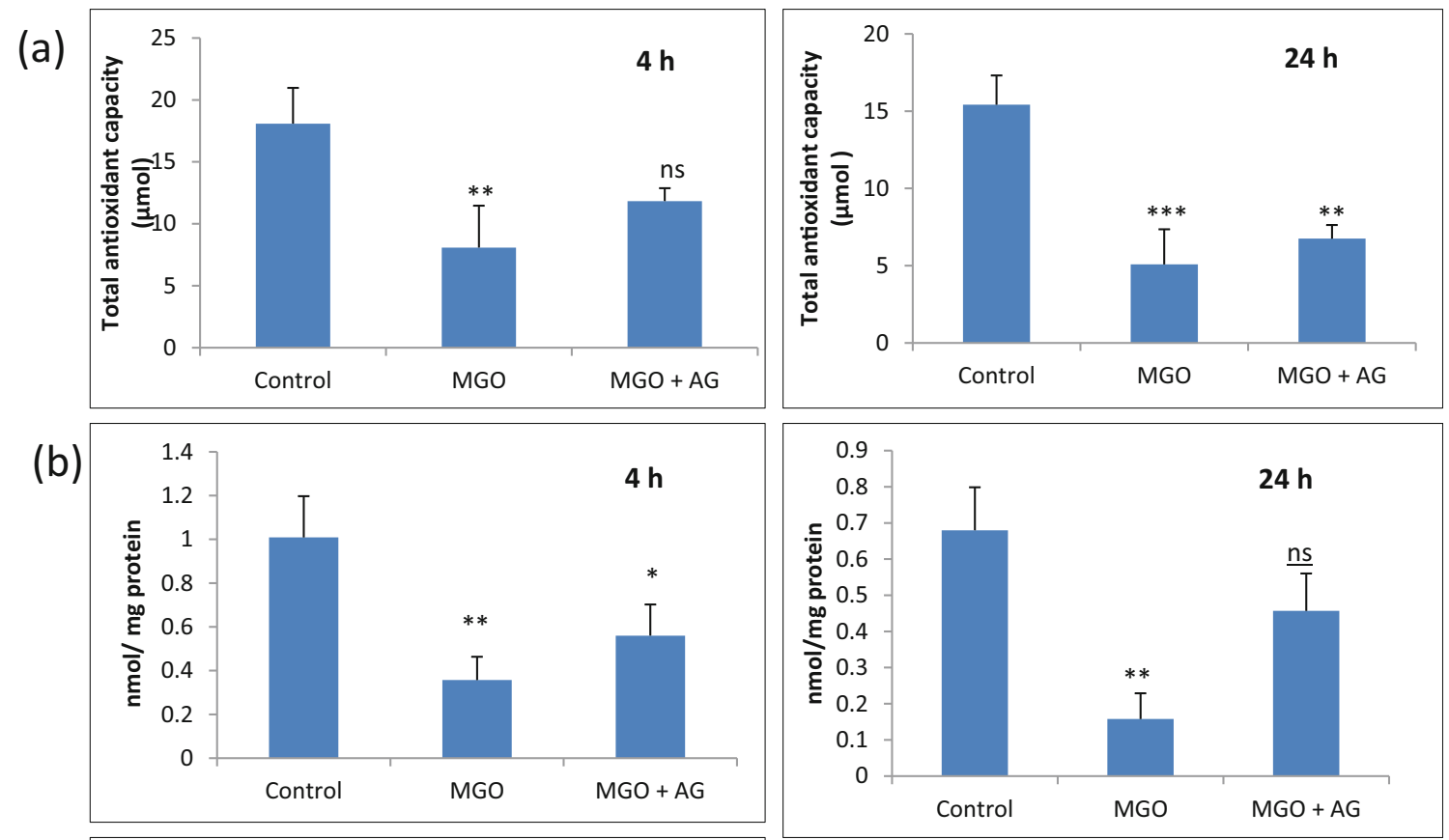

(c)
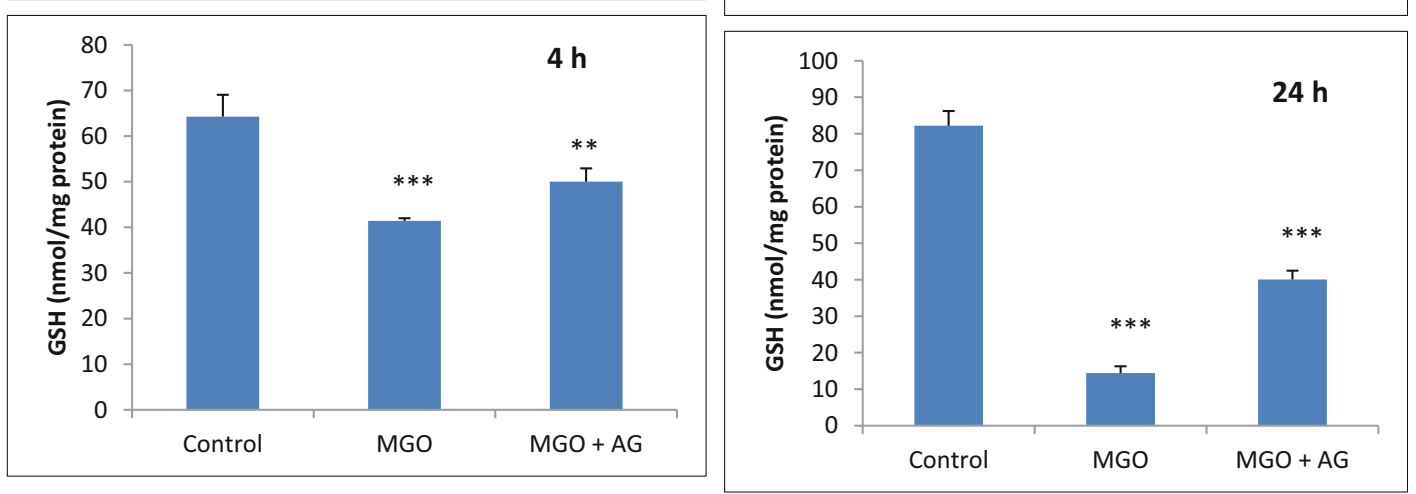

(d)
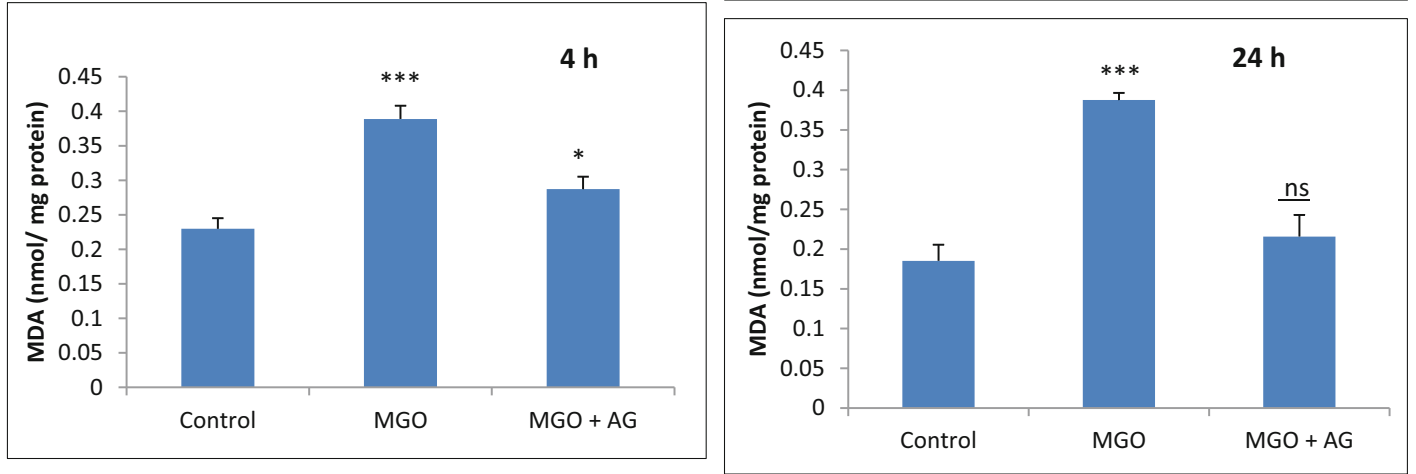

Fig. 4 Effect of MGO on oxidative stress markers of yeast cellular protein for $4 \mathrm{~h}$ and $24 \mathrm{~h}$. a Total antioxidant activity, b catalase activity, c GSH content, and $\mathbf{d}$ lipid peroxidation. Results are expressed as mean \pm $\mathrm{SD}, n=3$. The significance of the result is determined by comparing the

untreated control and inhibitory control with MGO-treated yeast cells using one-way ANOVA and represented as $* p<0.05, * * p<0.01$, $* * * p<0.001$

attached to an exposed free amino group of a protein, modifying its structure and inactivating the protein function. The thiol group acts as an antioxidant by protecting the cell against oxidative damage. It is clear from the results that free thiol group gets oxidized upon glycation with MGO, and more reduction in the levels were observed for $24 \mathrm{~h}$ samples than
$4 \mathrm{~h}$. Secondly, MGO-degrading enzyme glyoxylase activities may also cause the differential response in the two time points (Gomes et al. 2006).

MGO-derived AGEs can cause DNA damage by forming nucleotide adducts (Murata-Kamiya et al. 1997) and glycation of DNA increases mutagenesis and cytotoxicity (Lorenzi et al. 
Fig. 5 MGO induced glycation modifications in yeast protein and DNA

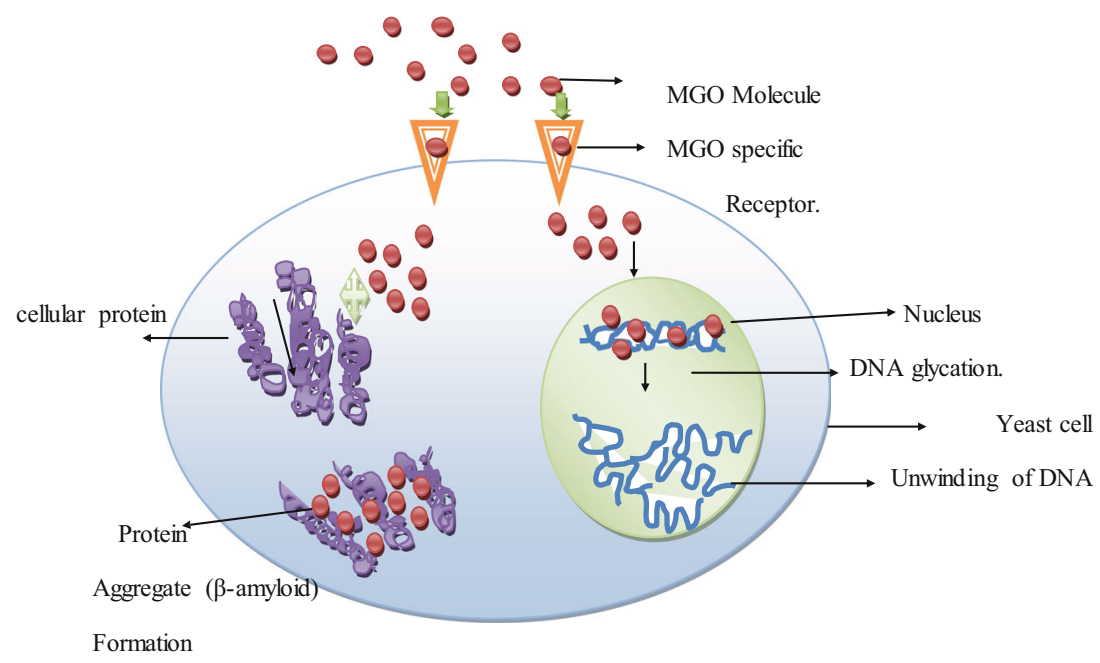

1986). It has been reported that endothelial cells incubated under hyperglycemic condition showed DNA strand breakage (Kasai et al. 1998). No structures have been characterized for inter-strand cross-links formed in duplex DNA at higher MGO concentration. For yeast DNA glycated with $8 \mathrm{mM}$ MGO for $24 \mathrm{~h}$, the fructosamine level and amyloid content were higher as compared to untreated and inhibitory control. Higher DNA denaturation was observed in glycated DNA as compared to inhibitory control. Melting temperatures of glycated DNA, untreated, and inhibitory control were $78^{\circ} \mathrm{C}, 83{ }^{\circ} \mathrm{C}$, and $81{ }^{\circ} \mathrm{C}$, respectively, indicating denaturation of DNA in the treated cells. Glycation of nitrogenous bases of DNA forms DNAbound AGEs and nucleotide adducts causes disruption of more hydrogen bonds separating both the strands (Roy et al. 2016).

Antioxidants are released into an oxidative-stressed cell to protect from ROS and cell death (Rattray et al. 1975). Free radical scavenger GSH and catalase enzyme levels were found to be decreased in glycated yeast cell as compared to untreated and inhibitory control. This might be due to the fact that antioxidant molecules were unable to cope with the increased oxidative stress. Due to the high rate of oxidation reactions, cellular antioxidant molecules cannot neutralize the increased ROS which results in decreased total antioxidant potential of the cell. Phospholipids are the main structural component of yeast cell membrane and essential for the viability of the cell. MGO oxidized polyunsaturated lipid content of yeast cell membrane, resulting in the formation of MDA, an unstable secondary product of lipid oxidation. MDA is known to cause DNA damage through free radical generation (Grotto et al. 2009). Higher levels of MDA are reported in type 2 diabetic patients (Fu et al. 1996).

\section{Conclusion}

The presence of $8 \mathrm{mM} \mathrm{MGO}$ in the extracellular medium resulted in a significant increased level of protein and DNA glycation in yeast. These modifications were found to be time dependent as $24 \mathrm{~h}$ incubation with MGO resulted in higher late-stage glycation modifications as compared to $4 \mathrm{~h}$ incubation. DNA glycation parameters were found to be elevated along with structural changes as evident from higher hyperchromicity and lower melting temperature. A highly significant $(p<0.01)$ increase in cellular oxidative stress with decreased cellular antioxidant potential was also noted. The addition of AG along with MGO in treatment media significantly reduced glycation modifications. MGO-induced protein, DNA glycation, and oxidative stress in $S$. cerevisiae indicated the suitability of the yeast model to study biochemical pathways involved in diabetic complications and conformational pathologies.

Acknowledgments The authors thank Dr. Santosh Tupe for copy editing the manuscript.

Funding The financial assistance from Bharati Vidyapeeth (Deemed to be University) is gratefully acknowledged.

\section{Compliance with ethical standards}

Conflict of interest The authors declare that they have no conflict of interest.

Research involving human participants and/or animals N/A

Informed consent N/A

\section{References}

Acimovic JM, Jovanovic VB, Veselinovic MR, Sreckovic VD, Mandic LM (2011) Method for monitoring of the protein amino group changes during carbonylation. Clin Biochem 44:994-999

Aebi H (1984) Catalase in vitro. Methods Enzymol 105:121-126

Aguilera J, Prieto JA (2004) Yeast cells display a regulatory mechanism in response to methylglyoxal. FEMS Yeast Res 4:633-641 
Ansari NA, Moinuddin, Ali R (2011) Physicochemical analysis of polyL-lysine: an insight into the changes induced in lysine residues of proteins on modification with glucose. IUBMB Life 63:26-29

Ayyappan S, Philips S, Kumar CK, Vaithiyanandane V, Sasikala C (2015) Serum fructosamine a better indicator than glycated hemoglobin for monitoring gestational diabetes mellitus. J Pharm Bioallied Sci 7: S32-S34

Baig MH, Jan AT, Rabbani G, Ahmad K, Ashraf JM, Kim T, Min HS, Lee YH, Cho WK, Ma JY, Lee EJ, Choi I (2017) Methylglyoxal and advanced glycation end products: insight of the regulatory machinery affecting the myogenic program and of its modulation by natural compounds. Sci Rep 7:5916

Baraka-Vidot J, Navarra G, Leone M, Bourdon E, Militello V, Rondeau P (2014) Deciphering metal-induced oxidative damages on glycated albumin structure and function. Biochim Biophys Acta 1840:17121724

Benzie IF, Strain JJ (1996) The ferric reducing ability of plasma (FRAP) as a measure of antioxidant power: the FRAP assay. Anal Biochem 239:70-76

Birben E, Sahiner UM, Sackesen C, Erzurum S, Kalayci O (2012) Oxidative stress and antioxidant defense. World Allergy Organ J 5:9-19

Botstein D, Fink GR (2011) Yeast: an experimental organism for 21st century biology. Genetics 189:695-704

Ceriello A, Colagiuri S (2008) International Diabetes Federation guideline for management of postmeal glucose: a review of recommendations. Diabet Med 25:1151-1156

Dalle-Donne I, Rossi R, Giustarini D, Milzani A, Colombo R (2003) Protein carbonyl groups as biomarkers of oxidative stress. Clin Chim Acta 329:23-38

Ellman GL (1959) Tissue sulfhydryl groups. Arch Biochem Biophys 82: 70-77

Fu MX, Requena JR, Jenkins AJ, Lyons TJ, Baynes JW, Thorpe SR (1996) The advanced glycation end product, $\mathrm{N}$-(carboxymethyl) lysine, is a product of both lipid peroxidation and glycoxidation reactions. J Biol Chem 271:9982-9986

Gomes RA, Vicente Miranda H, Silva MS, Graça G, Coelho AV, Ferreira AE, Cordeiro C, Freire AP (2006) Yeast protein glycation in vivo by methylglyoxal: molecular modification of glycolytic enzymes and heat shock proteins. FEBS J 273:5273-5287

Gomes RA, Oliveira LM, Silva M, Ascenso C, Quintas A, Costa G, Coelho AV, Sousa Silva M, Ferreira AE, PoncesFreire A, Cordeiro C (2008a) Protein glycation in vivo: functional and structural effects on yeast enolase. Biochem J 416:317-326

Gomes RA, Vicente Miranda H, Sousa Silva M, Graça G, Coelho AV, do Nascimento Ferreira AE, Cordeiro C, Freire AP (2008b) Protein glycation and methylglyoxal metabolism in yeast: finding peptide needles in protein haystacks. FEMS Yeast Res 8:174-181

Grotto D, Maria LS, Valentini J, Paniz C, Schmitt G, Garcia SC, Pomblum VJ, Rocha JBT, Farina M (2009) Importance of the lipid peroxidation biomarkers and methodological aspects for malondialdehyde quantification. Quim Nova 32:169-174

Hartwell LH (2002) Nobel lecture: yeast and cancer. Biosci Rep 22:373394

Hoon S, Gebbia M, Costanzo M, Davis RW, Giaever G, Nislow C (2011) A global perspective of the genetic basis for carbonyl stress resistance. G3 (Bethesda) 1:219-231

Horvat S, Jakas A (2004) Peptide and amino acid glycation: new insights into the Maillard reaction. J Pept Sci 10:119-137

Inoue Y, Tsujimoto Y, Kimura A (1998) Expression of the glyoxalase I gene of Saccharomyces cerevisiae is regulated by high osmolarity glycerol mitogen-activated protein kinase pathway in osmotic stress response. J Biol Chem 273:2977-2983

International Diabetes Federation (2015) IDF diabetes Atlas. Brussels, Belgium: International Diabetes Federation. www.diabetesatlas. org/resources/2015-atlas.html . Accessed 29 Dec 2018
Ispolnov K, Gomes RA, Silva MS, Freire AP (2008) Extracellular methylglyoxal toxicity in Saccharomyces cerevisiae: role of glucose and phosphate ions. J Appl Microbiol 104:1092-1102

Kasai H, Iwamoto-Tanaka N, Fukada S (1998) DNA modifications by the mutagen glyoxal: adduction to $\mathrm{G}$ and $\mathrm{C}$, deamination of $\mathrm{C}$ and $\mathrm{GC}$ and GA cross-linking. Carcinogenesis 19:1459-1465

Klunk WE, Jacob RF, Mason RP (1999) Quantifying amyloid by Congo red spectral shift assay. Methods Enzymol 309:285-305

Lapolla A, Molin L, Traldi P (2013) Protein glycation in diabetes as determined by mass spectrometry. Int J Endocrinol 2013:412103

Li J, Liu D, Sun L, Lu Y, Zhang Z (2012) Advanced glycation end products and neurodegenerative diseases: mechanisms and perspective. J Neurol Sci 317:1-5

Lorenzi M, Montisano DF, Toledo S, Barrieux A (1986) High glucose induces DNA damage in cultured human endothelial cells. J Clin Invest 77:322-325

Maeta K, Izawa S, Inoue Y (2005) Methylglyoxal, a metabolite derived from glycolysis, functions as a signal initiator of the high osmolarity glycerol-mitogen-activated protein kinase cascade and calcineurin/ Crzl-mediated pathway in Saccharomyces cerevisiae. J Biol Chem 280:253-260

Matafome P, Sena C, Seiça R (2013) Methylglyoxal, obesity, and diabetes. Endocrine 43:472-484

Miranda C, Giner M, Montoya MJ, Vázquez MA, Miranda MJ, PérezCano R (2016) Influence of high glucose and advanced glycation end-products (AGEs) levels in human osteoblast-like cells gene expression. BMC Musculoskelet Disord 17:377

Miroliaei M, Aminjafari A, Ślusarczyk S, Nawrot-Hadzik I, Rahimmalek M, Matkowski A (2017) Inhibition of glycation-induced cytotoxicity, protein glycation, and activity of proteolytic enzymes by extract from Perovskia atriplicifolia roots. Pharmacogn Mag 13:S676-S683

Mohammadi S, Saberidokht B, Subramaniam S, Grama A (2015) Scope and limitations of yeast as a model organism for studying human tissue-specific pathways. BMC Syst Biol 9:96

Murata-Kamiya N, Kamiya H, Kaji H, Kasai H (1997) Glyoxal, a major product of DNA oxidation, induces mutations at G: $\mathrm{C}$ sites on a shuttle vector plasmid replicated in mammalian cells. Nucleic Acids Res 25:1897-1902

Petranovic D, Tyo K, Vemuri GN, Nielsen J (2010) Prospects of yeast systems biology for human health: integrating lipid, protein and energy metabolism. FEMS Yeast Res 10:1046-1059

Placer ZA, Cushman LL, Johnson BC (1966) Estimation of product of lipid peroxidation (malonyldialdehyde) in biochemical systems. Anal Biochem 16:359-364

Ponces Freire A, Ferreira A, Gomes R, Cordeiro C (2003) Anti-glycation defences in yeast. Biochem Soc Trans 31:1409-1412

Raghav A, Ahmad J, Alam K (2017) Nonenzymatic glycosylation of human serum albumin and its effect on antibodies profile in patients with diabetes mellitus. PLoS One 12:e0176970

Rattray JB, Schibeci A, Kidby DK (1975) Lipids of yeasts. Bacteriol Rev 39:197-231

Roy A, Kim JH (2014) Endocytosis and vacuolar degradation of the yeast cell surface glucose sensors Rgt2 and Snf3. J Biol Chem 289:72477256

Roy A, Hashmi S, Li Z, Dement AD, Cho KH, Kim JH (2016) The glucose metabolite methylglyoxal inhibits expression of the glucose transporter genes by inactivating the cell surface glucose sensors Rgt2 and Snf3 in yeast. Mol Biol Cell 27:862-871

Soaita I, Yin W, Rubenstein DA (2017) Glycated albumin modifies platelet adhesion and aggregation responses. Platelets 28:682-690

Stathopulos PB, Scholz GA, Hwang YM, Rumfeldt JA, Lepock JR, Meiering EM (2004) Sonication of proteins causes formation of aggregates that resemble amyloid. Protein Sci 13:3017-3027

Tan SC, Yiap BC (2009) DNA, RNA, and protein extraction: the past and the present. J Biomed Biotechnol 2009:574398 
Thornalley PJ (2003) Use of aminoguanidine (Pimagedine) to prevent the formation of advanced glycation endproducts. Arch Biochem Biophys 419:31-40

Uchida K, Kanematsu M, Sakai K, Matsuda T, Hattori N, Mizuno Y, Suzuki D, Miyata T, Noguchi N, Niki E, Osawa T (1998) Analytical biochemistry protein-bound acrolein: potential markers for oxidative stress. Proc Natl Acad Sci U S A 95:4882-4887

Vlassara H, Uribarri J (2014) Advanced glycation end products (AGE) and diabetes: cause, effect, or both? Curr Diab Rep 14:453
Wani A, Mushtaq S, Ahsan H, Ahmad R (2012) Biochemical studies of in vitro glycation of human DNA. Asian J Biom Pharma Sci 2:2327

Winther JR, Thorpe C (2014) Quantification of thiols and disulfides. Biochim Biophys Acta 1840:838-846

Publisher's note Springer Nature remains neutral with regard to jurisdictional claims in published maps and institutional affiliations. 